\title{
Obstructive sleep apnea and driving: A Canadian Thoracic Society and Canadian Sleep Society position paper
}

\author{
Najib Ayas MD MPH FRCPC ${ }^{1}$, Robert Skomro MD FRCPC ${ }^{2}$, Adam Blackman MD FRCPC ${ }^{3,4}$, Kristen Curren MA ${ }^{5}$, \\ Michael Fitzpatrick MD FRCPC ${ }^{6}$, John Fleetham MD FRCPC ${ }^{1}$, Charles George MD FRCPC ${ }^{7}$, Tom Hakemi LLB ${ }^{8}$, \\ Patrick Hanly MD FRCPC ${ }^{9}$, Christopher Li MD FRCPC ${ }^{3}$, Debra Morrison MD FRCPC ${ }^{10}$, Frédéric Series MD FRCPC ${ }^{11}$
}

N Ayas, R Skomro, A Blackman, et al. Obstructive sleep apnea and driving: A Canadian Thoracic Society and Canadian Sleep Society position paper. Can Respir J 2014;21(2):114-123.

Untreated patients with obstructive sleep apnea (OSA) are at increased risk for motor vehicle collisions; however, it is unclear how this should be translated into fitness-to-drive recommendations. Accordingly, the Canadian Thoracic Society (CTS) Sleep Disordered Breathing Clinical Assembly and the Canadian Sleep Society (CSS) assembled a CTS-CSS working group to propose recommendations with regard to driving in patients with OSA.

Recommendations for assessing fitness to drive in noncommercial drivers: 1. Severity of OSA alone is not a reliable predictor of collision risk and, therefore, should not be used in isolation to assess fitness to drive; 2 . The severity of sleep apnea should be considered in the context of other factors to assess fitness to drive; 3 . The decision to restrict driving is ultimately made by the motor vehicle licensing authority; however, they should take into account the information and recommendations provided by the sleep medicine physician and should follow provincial guidelines; 4. For patients prescribed continuous positive airway pressure (CPAP) therapy, objective CPAP compliance should be documented. Efficacy should also be documented in terms of reversing the symptoms and improvement in sleep apnea based on physiological monitoring; 5. For patients treated with surgery or an oral appliance, verification of adequate sleep apnea treatment should be obtained; and 6. A driver diagnosed with OSA may be recertified as fit to drive based on assessment of symptoms and demonstrating compliance with treatment. The assessment should be aligned with the provincial driver's license renewal period.

Commercial vehicles: Assessment of fitness to drive should be more stringent for patients operating commercial vehicles. In general, the CTS-CSS working group was in agreement with the Medical Expert Panel recommendations to the Federal Motor Carrier Safety Administration in the United States; these recommendations were adapted for Canadian practitioners.

Key Words: Collisions; Commercial drivers; Diagnosis; Driving; Sleep apnea; Sleepiness

$\mathrm{D}$ riving a motor vehicle is a complex activity that relies on operator vigilance to prevent collisions. Sleepiness, regardless of cause, impairs performance during driving and increases the risk for motor vehicle collisions (MVCs) $(1,2)$.

Patients with obstructive sleep apnea (OSA) experience recurrent episodes of upper airway collapse during sleep. OSA causes sleep fragmentation, poor sleep quality and, consequently, daytime sleepiness and reduced vigilance. OSA (ie, apnea-hypopnea index $[\mathrm{AHI}]>5$ events/h) is a very common condition, found in approximately $24 \%$ of unselected middle-age men and $9 \%$ of middle-age women. A survey published in 2009 by the Public Health Agency of Canada indicated that 22\% (5.4 million) of adult Canadians report either being diagnosed with

\section{L'apnée obstructive du sommeil et la conduite automobile : déclaration de la Société canadienne de thoracologie et de la Société canadienne du sommeil}

Les patients atteints d'apnée obstructive du sommeil (AOS) qui ne sont pas traités sont plus vulnérables aux accidents d'automobile, mais on ne sait pas si cette observation devrait se traduire par des recommandations sur l'aptitude à la conduite. Ainsi, l'Assemblée clinique des troubles respiratoires du sommeil de la Société canadienne de thoracologie (SCT) et la Société canadienne du sommeil (SCC) ont formé un groupe de travail conjoint pour proposer aux patients atteints d'AOS des recommandations relatives à la conduite automobile.

Recommandations pour évaluer l'aptitude à la conduite chez les conducteurs non commerciaux : 1. La gravité de l'AOS n'est pas un prédicteur fiable du risque de collision et, par conséquent, ne doit pas être utilisée isolément pour évaluer l'aptitude à la conduite. 2. La gravité de l'apnée du sommeil devrait être prise en compte avec d'autres facteurs pour évaluer l'aptitude à la conduite. 3. La décision finale de restreindre la conduite incombe au bureau d'immatriculation, qui devrait toutefois tenir compte de l'information et des recommandations du médecin spécialisé en médecine du sommeil et respecter les directives provinciales. 4. Chez les patients traités par ventilation à pression positive continue, il faudrait consigner objectivement la compliance au traitement. Il faudrait également en consigner l'efficacité à renverser les symptômes et à atténuer l'apnée du sommeil, selon une surveillance physiologique. 5. Chez les patients soignés par chirurgie ou dispositif oral, il faudrait s'assurer que le traitement de l'apnée du sommeil fonctionne bien. 6. Un conducteur à qui on diagnostique une $\mathrm{AOS}$ peut redevenir apte à conduire, compte tenu de l'évaluation de ses symptômes et de la preuve de son respect du traitement. Cette évaluation devrait avoir lieu lors de la période de renouvellement provincial de son permis.

Véhicules commerciaux : L'évaluation de l'aptitude à la conduite devrait être plus rigoureuse chez les patients au volant de véhicules commerciaux. En général, le groupe de travail SCT-SCC approuvait les recommandations du groupe d'experts médicaux de la Federal Motor Carrier Safety Administration des États-Unis. Il les a adaptées à l'intention des praticiens canadiens.

sleep apnea (3\%) or are at high risk for OSA (19\%) (3). Moderate to severe disease (AHI $>15$ events/h) is found in $9 \%$ of men and $4 \%$ of women (4).

Given the impact of OSA on sleep quality and daytime sleepiness, it is not surprising that untreated patients with OSA experience an increased rate of MVCs. In observational studies, patients with OSA had a two- to 10-fold increased risk for collision compared with controls $(5,6)$. In the United States, it is estimated that approximately 800,000 drivers are involved in OSA-related collisions per year, costing society $\$ 15.9$ billion annually (7). Treatment of OSA mitigates these risks, with patients adherent to therapy experiencing a risk for MVC similar to that of age-matched controls (8).

${ }^{1}$ Univeristy of British Columbia, Vancouver, British Columbia; ${ }^{2}$ University of Saskatchewan, Saskatoon, Saskatchewan; ${ }^{3}$ University of Toronto;

${ }^{4}$ MedSleep, Toronto; ${ }^{5}$ Canadian Thoracic Society, Ottawa; ${ }^{6}$ Queen's University, Kingston; ${ }^{7}$ University of Western Ontario, London, Ontario;

${ }^{8}$ Hakemi $\mathcal{B}$ Ridgedale LLP, Vancouver, British Columbia; ${ }^{9}$ University of Calgary, Calgary, Alberta; ${ }^{10}$ Dalhousie University, Halifax, Nova

Scotia; ${ }^{11}$ Laval University, Québec City, Québec

Correspondence and reprints: Dr Najib Ayas, Canadian Thoracic Society, Lung Association - National Office, 300-1750 Courtwood Crescent,

Ottawa, Ontario K2C 2B5. Telephone 613-569-6411, fax 613-569-8860, e-mail ctsinfo@lung.ca 
Although it is well established that patients with OSA are at an increased risk for MVCs, what is less clear is how this should be translated into fitness-to-drive recommendations. The present position statement was developed in response to a lack of a Canadian position on driving and OSA. There are significant provincial variations in fitness-to-drive recommendations and, accordingly, the present document suggests a minimum set of standards that should be seriously considered for national discussion and adoption.

Our major goals were to provide an overview of provincial regulations regarding driving in patients with OSA, and to propose guidelines with respect to the issue of driving in patients with OSA. The present document should complement other recent guidelines on similar topics (9) and is intended for all health care professionals involved in the care of patients with OSA, commercial drivers, decision makers in health care and transportation, and patients with OSA. In the future, the Sleep Disordered Breathing Clinical Assembly intends to review and update the position, including questions and content, and identify new and emerging gaps and priorities as resources become available within a five-year cycle.

\section{METHODS}

To address the issue of driving in patients with OSA, the Canadian Thoracic Society (CTS) Sleep Disordered Breathing Clinical Assembly partnered with the Canadian Sleep Society (CSS) and a CTS-CSS working group was assembled. The group was chaired by Drs Ayas and Skomro and included academic physicians with expertise in sleep medicine across Canada.

The CTS-CSS working group conducted an environmental scan of all existing Canadian provincial guidelines for driving in patients with OSA. In addition to the environmental scan, the working group used the Medical Expert Panel (MEP) Recommendations on Obstructive Sleep Apnea and Commercial Motor Vehicle Driver Safety (10) that was submitted to the Federal Motor Carrier Safety Administration (FMCSA) in the United States as a foundational document to guide their analysis. However, the variations in Canadian fitness-to-drive recommendations and an overall lack of literature prompted the need for further discussions and, as a result, a workshop was organized. A workshop meeting was conducted in Vancouver, British Columbia, on April 26, 2012 to seek input from key stakeholders. This meeting included the working group and representatives of the Alberta, British Columbia and Saskatchewan Lung Associations, representatives from the Ministry of Health (British Columbia) and the Superintendant of Motor Vehicles (British Columbia), and a practicing lawyer to provide a legal perspective. (Representatives from the British Columbia Trucking Association and the Canadian Trucking Alliance were invited to the workshop meeting, but they did not attend) Before this meeting, the working group conducted three teleconferences and substantial e-mail correspondence to discuss the format and agenda of the meeting. Three major topics were believed to be of utmost importance with regard to OSA and driving, and were specifically discussed in the face-to-face workshop meeting (see below).

At the workshop meeting, the current guidelines for driving in patients with OSA in each Canadian province were presented by Dr Fleetham. The MEP guidelines regarding OSA and commercial motor vehicle driver safety were presented by Dr George, who was a member of the MEP. Potential legal issues regarding this topic were discussed as a group.

The participants focused on three major areas during this face-toface meeting:

1. Which noncommercial drivers with OSA should be considered not fit to drive?;

2. When should patients, who have been restricted from driving, and whose OSA has subsequently been treated, be allowed to drive again? What is the recommended follow up?; and

3. Should recommendations be different for commercial drivers? If so, how? Should all professional/commercial drivers be screened for OSA? If so, how?
The first topic was discussed by the entire group. The latter two were discussed in two separate breakout groups, which then presented their recommendations to the entire group to reach consensus. These questions had been precirculated to the workshop participants along with the CTS 2011 guideline update (Diagnosis and treatment of sleep disordered breathing [11]), the Canadian Medical Association's "Determining the Fitness to Operate Motor Vehicles - A Guide for Physicians" (12), MEP recommendations to the FMCSA (13) and a compilation of current practices in Canadian provinces.

A draft document that summarized the discussions was prepared by the chairs and sent to the working group for input and modification. Once feedback was received, the working group convened a consensus teleconference. After review of the evidence, and significant discussion and several rounds of voting, final consensus was reached on the key messages by the entire CTS-CSS working group via an anonymous voting process. The completed document was subsequently sent to three external experts in the field of sleep apnea for their external review. This document was then approved by the Canadian Respiratory Guidelines Committee, the CTS Executive and the Executive of the CSS. The document was developed in accordance with CTS requirements for a position paper (14).

\section{RESULTS}

\section{Review of provincial and other guidelines}

A summary of the guidelines for assessment of fitness to drive for each province in Canada is presented in Table 1. The variability of recommendations across the provinces reflects the fact that driving safety is a provincial - not a federal - responsibility.

In the discussion, a distinction was made between the requirement to report and recommendation to restrict driving. For example, in Ontario, a physician may have a duty to report a patient with OSA, but can also recommend that the patient's license not be restricted if he/she is not believed to be at high risk for experiencing an MVC.

\section{Review of MEP recommendations to the FMCSA}

An expert panel consisting of Drs Sonia Ancoli-Israel, Charles Czeisler, Charles George, Christian Guilleminault and Allan Pack made recommendations with respect to OSA and drivers of commercial vehicles, including large trucks and buses. The recommendations were originally submitted to the FMCSA in January 2008 and were based on review of current scientific data and extensive discussion over a two-day meeting. These recommendations were then revised in February 2012 by the OSA Subcommittee, which included members from FMCSA's Motor Carrier Safety Advisory Committee and Medical Review Board (Table 2) (10).

These guidelines were reviewed by the CTS-CSS working group and discussed at length, specifically with respect to the applicability of the guidelines in Canada. Of note, the MEP recommendations were designed to inform motor carriers, commercial drivers and medical examiners guidance with respect to determination of a driver's ability to operate a motor vehicle. These rigorous recommendations apply to a driver undergoing a fitness-to-drive assessment at the direction of the licensing authority, and may not be applicable to decisions made during a regular clinical encounter with a patient.

\section{Legal considerations}

A physician whose patient with OSA drives and is involved in a MVC faces several potential sources of liability. There may be regulatory liability based on rules of professional conduct that apply to physicians and/or there may be other laws that impose liability (eg, motor vehicle legislation). There may also be civil liability to the patient/driver and/ or the victims of the collision, which is determined by whether the conduct of the physician was inconsistent with what is considered to be reasonable practice.

The presence of a published position statement may impact an adjudicator's findings with respect to the reasonableness of the physician's conduct under the circumstances at hand, which may impact a 
TABLE 1

Provincial regulations regarding driving in patients with obstructive sleep apnea (OSA)*

\begin{tabular}{|c|c|}
\hline Province (reference) & Regulations \\
\hline British Columbia (30) & $\begin{array}{l}\text { 1) OSA untreated } \\
\text { Private drivers (Class } 5 \text { to } 8 \text { ) } \\
\text { Individuals who have OSA that is untreated may drive if: } \\
\text { - they have no history of sleep-related motor vehicle crashes or sleep at the wheel in the past } 5 \text { years } \\
\text { - the results of a SIMARD test (Screen for the Identification of Cognitively Impaired Medically At-Risk Drivers) indicate that they have } \\
\text { sufficient cognitive function to drive or, where required, an on-road driving assessment indicates that they are fit to drive } \\
\text { - they understand the nature of their condition and the potential impact on fitness to drive, and they agree to report any episodes of } \\
\text { sleep at the wheel to their treating physician and the office of the superintendant of motor vehicles. } \\
\text { Commercial drivers (Class } 1 \text { to } 4 \text { ) } \\
\text { Individuals who have OSA that is untreated may drive if they meet the guidelines of Private Drivers with untreated OSA, and they have } \\
\text { not declined further investigation or treatment of OSA in which it has been recommended by a treating physician. } \\
\text { 2) OSA treated, all licence classes } \\
\text { Individuals who have OSA that is being treated or has been treated surgically may drive if the effectiveness of their treatment has been } \\
\text { established through repeat sleep monitoring. Where applicable, they remain compliant with their treatment regime. For CPAP treatment, } \\
\text { compliance means a minimum of } 4 \mathrm{~h} \text { of use on at least } 70 \% \text { of nights, objectively documented. The results of a SIMARD test indicate } \\
\text { that they have sufficient cognitive function to drive, or where required, an on road driving assessment indicates that they are fit to drive, } \\
\text { they understand the nature of their condition and the potential impact on fitness to drive, and they agree to report any episodes of sleep } \\
\text { at the wheel to their treating physician and the office of the superintendant of motor vehicles. }\end{array}$ \\
\hline Alberta (31) & $\begin{array}{l}\text { It is primarily the responsibility of the patient with OSA to inform the Ministry of Transportation of their condition. Patients are given this } \\
\text { information. Individual patients may be reported to the Ministry of Transportation by a treating physician if there is a serious concern } \\
\text { about noncompliance in a safety-critical occupation. }\end{array}$ \\
\hline Saskatchewan ${ }^{\dagger}$ & $\begin{array}{l}\text { Standard } \\
\text { All drivers eligible for a license if: } \\
\text { - Has untreated obstructive sleep apnea with an } \mathrm{AHI}<20 \text { events/h, and has no daytime sleepiness or, } \\
\text { - Has obstructive sleep apnea that is treated successfully } \\
\text { - May not operate any class of vehicle if has experienced a crash associated with falling asleep or reports excessive sleepiness } \\
\text { - while driving until the sleep disorder has been treated successfully } \\
\text { - The conditions for maintaining a license are met } \\
\text { Conditions for maintaining license } \\
\text { - All commercial drivers must file periodic mandatory medical reports to assess their fitness to hold a commercial license. } \\
\text { - Noncommercial drivers are assessed for fitness to drive on a case by case basis, taking into account the treating physician's } \\
\text { - } \text { specific recommendations. } \\
\text { Reassessment } \\
\text { - At the discretion of the authority for noncommercial drivers. } \\
\text { - Annual medical review for commercial drivers with OSA. } \\
\text { SGI medical review } \\
\text { Can drive if: } \\
\text { - Any class, if untreated and AHI <20 events/h and there is no daytime sleepiness } \\
\text { - Any class, if sleep apnea treated }\end{array}$ \\
\hline Manitoba $\ddagger$ & $\begin{array}{l}\text { May not operate any class of vehicle if has experienced a crash associated with falling asleep, or reports excessive sleepiness while } \\
\text { driving until the sleep disorder has been successfully treated } \\
\text { Diagnosis confirmed by sleep study, class } 1-5 \\
\text { May drive if physician supports driving. Physician indicates excessive daytime sleepiness while driving is controlled by treatment and } \\
\text { compliant with treatment. Has untreated OSA with AHI <20 events/h and has no daytime sleepiness. } \\
\text { Diagnosis unconfirmed, class } 1-5 \\
\text { May drive if physician supports driving. Physician indicates no excessive daytime sleepiness while driving and sleepiness never so abrupt } \\
\text { the person cannot take evasive action. }\end{array}$ \\
\hline Ontario (32) & $\begin{array}{l}\text { Every legally qualified medical practitioner shall report to the Registrar the name, address and clinical condition of every person } 16 \text { years } \\
\text { of age or over attending upon the medical practitioner for medical services who, in the opinion of the medical practitioner, is suffering } \\
\text { from a condition that may make it dangerous for the person to operate a motor vehicle. This does not specifically address OSA, but } \\
\text { OSA is considered to be one of the conditions that "may make it dangerous for the person to operate a motor vehicle". The Ontario } \\
\text { Medical Association (OMA) disagrees with the Highway traffic act. It is their (legal) opinion that the law captures many patients who may } \\
\text { not actually be a threat. However, there is a form which the OMA encourages physicians to fill out - but advises that the comment } \\
\text { section indicate: "This condition is unlikely to present a safety risk" or "Condition does not appear to pose a threat". In this way where } \\
\text { appropriate, physicians can comply with the law and protect patients from unnecessary scrutiny by Ministry of Transportation. }\end{array}$ \\
\hline Quebec (33) & $\begin{array}{l}\text { Follow Canadian Council of Motor Transport Administrators Determining Driver Fitness in Canada, 13th Edition, except that the } \\
\text { acceptable upper limit for AHI in nonsomnolent patients is } 30 \text { events/h. }\end{array}$ \\
\hline Prince Edward Island & Unable to obtain any specific guidelines \\
\hline New Brunswick (12) & Follow CMA Driver’s Guide: Determining Medical Fitness to Operate Motor Vehicles, 8th Edition \\
\hline
\end{tabular}


TABLE 1 - CONTINUED

Provincial regulations regarding driving in patients with obstructive sleep apnea (OSA)*

\begin{tabular}{|l|l|}
\hline Province (reference) & Regulations \\
\hline Nova Scotia (34) & $\begin{array}{l}\text { A physician may report to the Department of Motor Vehicles the name of any patient who in the physician's opinion has infirmities or } \\
\text { disabilities rendering the patient unsafe to drive. The provincial medical board has subsequently written the following: "There is a general } \\
\text { duty to the public when it comes to driving a vehicle. Doctors have a duty under common law. If for no other reason, physicians in } \\
\text { Nova Scotia should take care in reporting infirmities and disabilities which render it unsafe for patients to operate a motor vehicle, even } \\
\text { though reporting is not mandatory. You are legally protected if you do report. You may not be protected if you fail to report." }\end{array}$ \\
\hline Newfoundland (35) & Follow the Canadian Council of Motor Transport Administrators Medical Standards under the National Safety Code Section 6.4
\end{tabular}

*Data adapted from reference 3; †Personal communication, Saskatchewan Government Insurance, November 30, 2013; ¥Personal communication, Manitoba Public Insurance, November 30, 2013. AHI Apnea-hypopnea index; CMA Canadian Medical Association; CPAP Continuous positive airway pressure; SGI Saskatchewan Government Insurance

\section{TABLE 2}

Medical expert panel recommendations to the Federal Motor Carrier Safety Administration (FMCSA) for commercial vehicle driver safety (10) and recommendations for Canadian commercial drivers

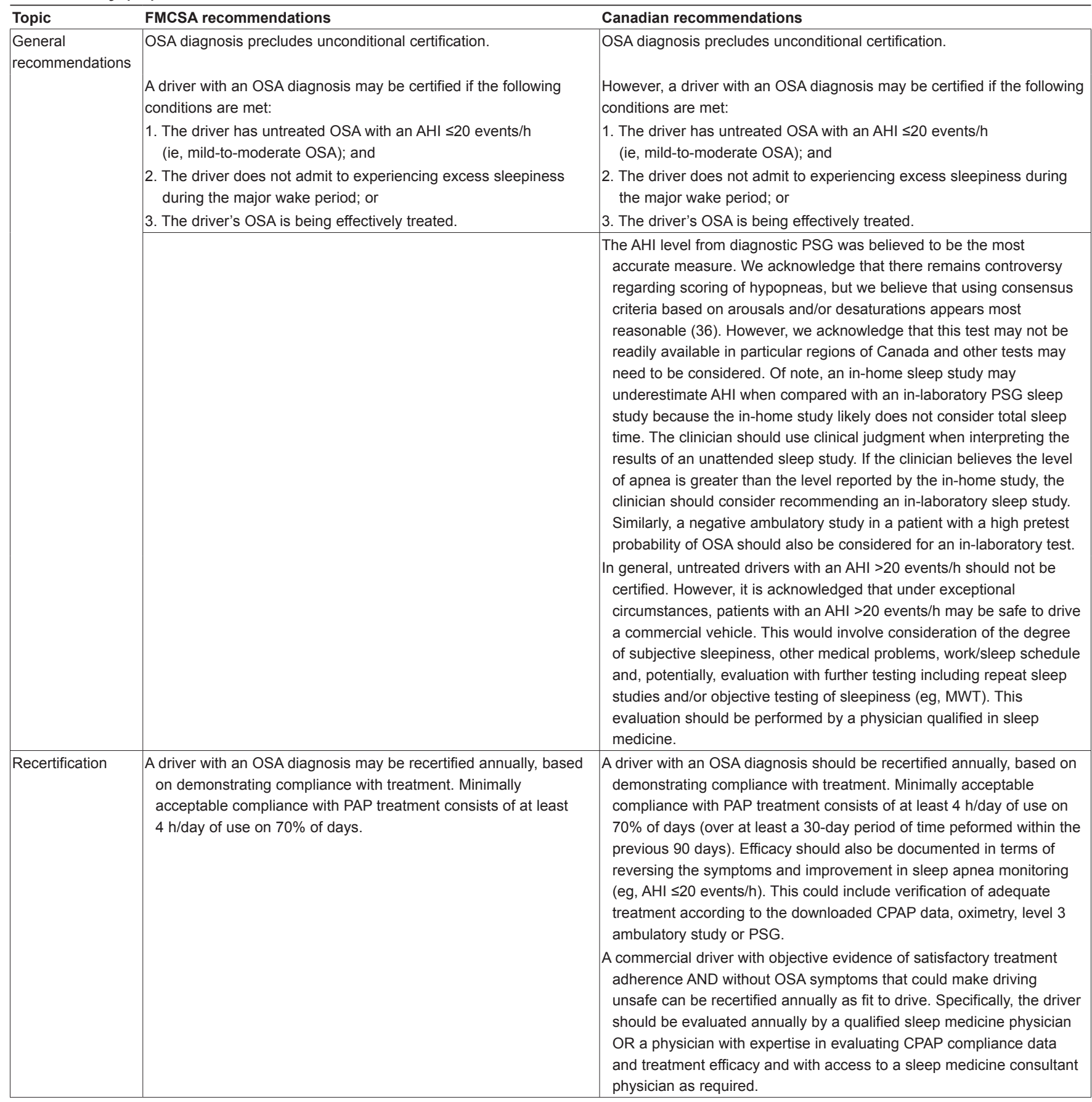


TABLE 2 - CONTINUED

Medical expert panel recommendations to the Federal Motor Carrier Safety Administration (FMCSA) for Commercial vehicle driver safety (10) and recommendations for Canadian commercial drivers

\begin{tabular}{|c|c|c|}
\hline Topic & FMCSA recommendations & Canadian recommendations \\
\hline $\begin{array}{l}\text { Immediate } \\
\text { disqualification } \\
\text { or certification } \\
\text { denial }\end{array}$ & $\begin{array}{l}\text { Drivers should be disqualified immediately or denied certification if } \\
\text { any of the following conditions are met: } \\
\text { 1. The driver admits to experiencing excessive sleepiness during } \\
\text { the major wake period while driving; or } \\
\text { 2. The driver experienced a crash associated with falling asleep; or } \\
\text { 3. The driver has been found to be noncompliant with treatment. }\end{array}$ & $\begin{array}{l}\text { Drivers should be disqualified immediately or denied certification if any of } \\
\text { the following conditions are met: } \\
\text { 1. The driver admits to experiencing excessive sleepiness during the } \\
\text { major wake period while driving, or } \\
\text { 2. The driver experienced a crash associated with falling asleep in the } \\
\text { past five years if effective therapy has not been instituted in the interim; or } \\
\text { 3. The driver has been found to be noncompliant with treatment. }\end{array}$ \\
\hline \multirow[t]{5}{*}{$\begin{array}{l}\text { Conditional } \\
\text { certification }\end{array}$} & $\begin{array}{l}\text { Drivers may be granted conditional certification if any of the } \\
\text { following conditions are met: } \\
\text { 1. The driver has an } \mathrm{AHI}>20 \text { events } / \mathrm{h} \text { until compliant with PAP; or } \\
\text { 2. The driver has undergone surgery and is pending postoperative } \\
\text { findings; or } \\
\text { 3. The driver has a body mass index of } \geq 35 \mathrm{~kg} / \mathrm{m}^{2} \text { pending } \\
\text { a sleep study. }\end{array}$ & $\begin{array}{l}\text { Drivers may be granted conditional certification if any of the following } \\
\text { conditions are met: } \\
\text { 1. The driver has an } \mathrm{AHI}>20 \text { events } / \mathrm{h} \text { until compliant with PAP, or } \\
\text { 2. The driver has undergone surgery and is pending follow-up monitoring } \\
\text { of sleep and symptoms, or } \\
\text { 3. The driver has a body mass index } \geq 35 \mathrm{~kg} / \mathrm{m}^{2} \text { pending a sleep study. }\end{array}$ \\
\hline & $\begin{array}{l}\text { Conditional certification should include the following elements: } \\
\text { 1. A driver with a body mass index } \geq 35 \mathrm{~kg} / \mathrm{m}^{2} \text { may be certified for } \\
60 \text { days pending sleep study and treatment (if the driver is } \\
\text { diagnosed with OSA). } \\
\text { 2. Within } 60 \text { days, if a driver being treated with OSA is compliant } \\
\text { with treatment, the driver may receive an additional } 90 \text {-day } \\
\text { conditional certification. } \\
\text { 3. After } 90 \text { days, if the driver is still compliant with treatment, } \\
\text { the driver may be certified for no more than } 1 \text { year. Future } \\
\text { certification should be dependent on continued compliance. }\end{array}$ & $\begin{array}{l}\text { Conditional certification should include the following elements: } \\
\text { 1. A driver with a body mass index } \geq 35 \mathrm{~kg} / \mathrm{m}^{2} \text { may be certified for } \\
60 \text { days pending sleep study and treatment (if the driver is diagnosed } \\
\text { with OSA). } \\
\text { 2. Within } 60 \text { days, if a driver started on treatment for OSA is compliant } \\
\text { with treatment (over a one week time period), the driver may receive } \\
\text { an additional } 90 \text {-day conditional certification. Efficacy should also be } \\
\text { documented in terms of reversing the symptoms and improvement in } \\
\text { sleep apnea monitoring (eg, AHI } \leq 20 \text { events/h). This could include } \\
\text { verification of adequate treatment according to the downloaded CPAP } \\
\text { data, oximetry, level } 3 \text { ambulatory study or PSG. } \\
\text { 3. After } 90 \text { days, if the driver is still compliant with treatment, the driver } \\
\text { may be certified for no more than } 1 \text { year. Future certification should be } \\
\text { dependent on continued compliance, reversing symptoms, and } \\
\text { persistent improvement in sleep apnea monitoring. }\end{array}$ \\
\hline & $\begin{array}{l}\text { Methods of diagnosis include in-laboratory PSG, at-home PSG or } \\
\text { a Food and Drug Administration-approved limited channel } \\
\text { ambulatory testing device that ensures chain of custody. } \\
\text { In-laboratory PSG, which is more comprehensive, should be } \\
\text { considered when the clinician suspects another sleep disorder in } \\
\text { addition to sleep apnea. }\end{array}$ & \\
\hline & $\begin{array}{l}\text { New OSA screening technologies will likely emerge. } \\
\text { The driver should be tested while on usual chronic medications. } \\
\text { The MCSAC and MRB did not consider AHI levels from unattended } \\
\text { (ie, in-home) studies, only in-laboratory sleep studies that detect } \\
\text { the arousal component of hypopneas as well as saturation. }\end{array}$ & \\
\hline & $\begin{array}{l}\text { 1. An in-home sleep study may underestimate AHI when compared } \\
\text { with an in-laboratory PSG sleep study because the in-home study } \\
\text { likely does not consider total sleep time. } \\
\text { 2. The medical examiner should use clinical judgment when } \\
\text { interpreting the results of an unattended sleep study. If the clinician } \\
\text { believes the level of apnea is greater than the level reported by the } \\
\text { in-home study, the clinician should consider recommending an } \\
\text { in-laboratory sleep study. }\end{array}$ & \\
\hline OSA screening & & $\begin{array}{l}\text { All commercial drivers should be screened for OSA based on } \\
\text { symptoms, questionnaires, and body mass index. Drivers at high risk } \\
\text { for OSA should be sent for confirmatory testing. Although a qualified } \\
\text { sleep medicine physician is not required to see every driver, a qualified } \\
\text { sleep medicine physician should oversee the screening, testing, and } \\
\text { treatment program acting as a resource for the driver's assessing } \\
\text { physician. } \\
\text { The driver should be tested while on usual chronic medications. } \\
\text { Methods of diagnosis include in-laboratory PSG, at-home PSG, or a } \\
\text { Health Canada-approved limited channel ambulatory testing device } \\
\text { (with chain of custody if available). } \\
\text { Please see comment in general recommendations regarding AHI from } \\
\text { PSG and ambulatory studies. } \\
\text { In-laboratory PSG, which is more comprehensive, should be considered } \\
\text { when the clinician suspects another sleep disorder in addition to sleep } \\
\text { apnea. } \\
\text { New OSA screening technologies will likely emerge but need to be } \\
\text { validated before use. }\end{array}$ \\
\hline
\end{tabular}


TABLE 2 - CONTINUED

Medical expert panel recommendations to the Federal Motor Carrier Safety Administration (FMCSA) for commercial vehicle driver safety (10) and recommendations for Canadian commercial drivers

\begin{tabular}{|c|c|c|}
\hline Topic & FMCSA recommendations & Canadian recommendations \\
\hline Treatment: PAP & $\begin{array}{l}\text { All individuals with OSA should be referred to a clinician with } \\
\text { relevant expertise. } \\
\text { PAP is the preferred OSA therapy. } \\
\text { Adequate PAP pressure should be established through one of the } \\
\text { following methods: Titration study with PSG or autotitration } \\
\text { system } \\
\text { A driver who has been disqualified may be conditionally certified if } \\
\text { the following conditions are met: } \\
\text { 1. The driver is successfully treated for one week; and } \\
\text { 2. The driver can demonstrate at least minimal compliance } \\
\text { (ie, } 4 \text { h per use on } 70 \% \text { of nights); and } \\
\text { 3. The driver does not report excessive sleepiness during the } \\
\text { major wake period. }\end{array}$ & $\begin{array}{l}\text { All individuals with OSA should be referred to a clinician with relevant } \\
\text { expertise (please see CSS/CTS position paper on the use of portable } \\
\text { monitoring for the diagnosis of obstructive sleep apnea/hypopnea in } \\
\text { adults [37] for description of relevant expertise) } \\
\text { PAP is the preferred OSA therapy. } \\
\text { Adequate PAP pressure should be established through one of the } \\
\text { following methods: Titration study with PSG or autotitration system } \\
\text { A driver who has been disqualified may be conditionally certified if the } \\
\text { following conditions are met: } \\
\text { 1. The driver is successfully treated for one week; and } \\
\text { 2. The driver can demonstrate at least minimal compliance } \\
\text { (ie, } 4 \text { h per use on } 70 \% \text { of nights); and } \\
\text { 3. The driver does not report excessive sleepiness during the major } \\
\text { wake period, and sleep monitoring (as assessed by PSG, ambulatory } \\
\text { study, and/or CPAP downloads) demonstrates improvement in AHI. } \\
\text { Ideally, the aim should be for an AHI <10 events/h on treatment, } \\
\text { although an AHI } \leq 20 \text { events/h would be acceptable. }\end{array}$ \\
\hline $\begin{array}{l}\text { Treatment: } \\
\text { Bariatric surgery }\end{array}$ & $\begin{array}{l}\text { After bariatric surgery, a driver may be certified if the following } \\
\text { conditions are met: } \\
\text { 1. Six months have passed since the surgery (for weight loss); and } \\
\text { 2. The driver has been compliant with PAP for six months; and } \\
\text { 3. The driver has been cleared by the treating physician; and } \\
\text { 4. The driver does not report excessive sleepiness during the } \\
\text { major wake period. } \\
\text { After six months have passed since surgery, if the apnea appears } \\
\text { to have resolved, a repeat sleep study should be considered to } \\
\text { test for the presence of ongoing sleep apnea. } \\
\text { Annual recertification: If clinically indicated, repeat the sleep study. }\end{array}$ & $\begin{array}{l}\text { After bariatric surgery, a driver may be certified to drive without other } \\
\text { treatment if the following conditions are met: } \\
\text { 1. Six months have passed since the surgery (for weight loss); and } \\
\text { 2. The driver does not report excessive sleepiness during the major } \\
\text { wake period; and } \\
\text { 3. There is resolution of substantial OSA (ie, AHI } \leq 20 \text { events/h) by PSG } \\
\text { or ambulatory monitoring without PAP or other active treatment. } \\
\text { If there is substantial sustained weight loss before } 6 \text { months, one could } \\
\text { consider testing earlier than } 6 \text { months. } \\
\text { Annual recertification: If clinically indicated, repeat the sleep study. } \\
\text { Similarly, if the patient has substantial weight loss through other means } \\
\text { (eg, diet), the driver does not report excessive sleepiness during the } \\
\text { major awake period and there is resolution of substantial OSA, the } \\
\text { driver may be certified as being fit to drive. }\end{array}$ \\
\hline $\begin{array}{l}\text { Treatment: } \\
\text { Oropharyngeal } \\
\text { surgery, facial } \\
\text { bone surgery }\end{array}$ & $\begin{array}{l}\text { After oropharyngeal or facial bone surgery, a driver may be } \\
\text { certified if the following conditions are met: } \\
\text { 1. One month has passed since surgery; and } \\
\text { 2. The driver has been cleared by the treating physician; and } \\
\text { 3. The driver does not report excessive sleepiness during the } \\
\text { major wake period. } \\
\text { After one month has passed since surgery, if the apnea appears to } \\
\text { have resolved, a repeat sleep study should be considered to test } \\
\text { for the presence of ongoing sleep apnea. } \\
\text { Annual recertification: If clinically indicated, repeat the sleep study. }\end{array}$ & $\begin{array}{l}\text { After oropharyngeal or facial bone surgery, a driver may be certified if } \\
\text { the following conditions are met: } \\
\text { 1. At least one month has passed since surgery, and } \\
\text { 2. The driver has been cleared by the treating physician, and } \\
\text { 3. The driver does not report excessive sleepiness during the major } \\
\text { wake period, and } \\
\text { 4. A repeat sleep study demonstrates resolution of substantial OSA } \\
\text { (AHI } \leq 20 \text { events/h) } \\
\text { Annual recertification: If clinically indicated, repeat the sleep study }\end{array}$ \\
\hline $\begin{array}{l}\text { Treatment: } \\
\text { Tracheostomy }\end{array}$ & $\begin{array}{l}\text { After a tracheostomy, a driver may be certified if the following } \\
\text { conditions are met: } \\
\text { 1. One month has passed since surgery, and } \\
\text { 2. The driver has been cleared by the treating physician, and } \\
\text { 3. The driver does not report excessive sleepiness during the } \\
\text { major wake period. } \\
\text { After one month has passed since surgery, if the apnea appears to } \\
\text { have resolved, a repeat sleep study should be considered to test } \\
\text { for the presence of ongoing sleep apnea. } \\
\text { Annual recertification: If clinically indicated, repeat the sleep study. }\end{array}$ & $\begin{array}{l}\text { After a tracheostomy, a driver may be certified if the following conditions } \\
\text { are met: } \\
\text { 1. One month has passed since surgery, and } \\
\text { 2. The driver has been cleared by the treating physician, and } \\
\text { 3. The driver does not report excessive sleepiness during the major } \\
\text { wake period. } \\
\text { After one month has passed since surgery, if the apnea appears to have } \\
\text { resolved, a repeat sleep study should be considered to test for the } \\
\text { presence of ongoing sleep apnea. } \\
\text { Annual recertification: If clinically indicated, repeat the sleep study. }\end{array}$ \\
\hline
\end{tabular}


TABLE 2 - CONTINUED

Medical expert panel recommendations to the Federal Motor Carrier Safety Administration (FMCSA) for commercial vehicle driver safety (10) and recommendations for Canadian commercial drivers

\begin{tabular}{|c|c|c|}
\hline Topic & FMCSA recommendations & Canadian recommendations \\
\hline $\begin{array}{l}\text { Treatment } \\
\text { alternatives }\end{array}$ & $\begin{array}{l}\text { There are limited data regarding compliance and long-term efficacy } \\
\text { of dental appliances, and these technologies are not approved } \\
\text { alternatives at this time. }\end{array}$ & \multirow[b]{2}{*}{$\begin{array}{l}\text { Oral appliances can be effective in select patients with OSA. Even } \\
\text { though one cannot verify objective compliance, the portability and } \\
\text { side-effect profile of the devices make it attractive for certain patients. } \\
\text { It was believed that certification with use of an oral appliance was } \\
\text { reasonable under the following circumstances: } \\
\text { 1. The driver has been cleared by the treating physician; and } \\
\text { 2. The driver does not report excessive sleepiness during the major } \\
\text { wake period; and } \\
\text { 3. Effectiveness of the device has been verified by a sleep study } \\
\text { (ideally with an AHI < } 10 \text { events/h, but AHI } \leq 20 \text { events/h would be } \\
\text { acceptable); and } \\
\text { 4. Reported compliance is at least } 70 \% \text { of nights over a } 30 \text {-day time period } \\
\text { If a validated technology is developed to objectively assess compliance, } \\
\text { use of this should be strongly considered. } \\
\text { Annual recertification. Repeat sleep study should be considered if there } \\
\text { is concern for device effectiveness (eg, weight gain, re-emergence of } \\
\text { snoring, sleepiness) }\end{array}$} \\
\hline & & \\
\hline
\end{tabular}

AHI Apnea-hypopnea index; CPAP Continuous positive airway pressure; CSS Canadian Sleep Society; CTS Canadian Thoracic Society; MCSAC Motor Carrier Safety Advisory Committee; MRB Medical Review Board; MWT Maintenance of wakefulness test; OSA Obstructive sleep apnea; PAP Positive airway pressure; PSG Polysomnography

finding of regulatory liability and civil liability (to the extent it impacts the standard of care analysis).

For patients with suspected sleep apnea referred to a specialist and not yet seen, or who have been seen but not been tested and have experienced an MVC, it is unlikely (although possible) that a physician would be held liable. The determination is likely to be case specific and much of it is likely to depend on what a reasonable physician would have done in similar circumstances.

\section{THREE MAJOR TOPICS DISCUSSED AT THE WORKSHOP MEETING}

Which noncommercial drivers with OSA should be considered not fit to drive?

This topic was discussed by the entire participant group, which made a distinction between the roles of the physician and that of the motor vehicle licensing authority. The role of the physician is to assess medical fitness to drive, while the role of the licensing authority is to determine eligibility to drive and issuing/restricting driving licenses. The decision of the licensing authority to restrict driving should take into account the information and recommendations provided by the sleep medicine physician and should follow provincial guidelines.

It was noted that although the risk for collision is greater in patients with OSA, the majority of patients will not experience such an event. A large part of the discussion revolved around whether any firm thresholds of sleep apnea severity or other indexes exist above which patients should be considered not fit to drive. One consideration was adopting the recommendations of the MEP to the FMCSA (AHI threshold $\geq 20$ events/ $h$ for drivers of commercial vehicles), and use this threshold for drivers of noncommercial vehicles. Another option was to consider a higher threshold (eg, AHI $>30$ events/h or $>40$ events/h) with physician judgment at lower levels of sleep apnea severity.

However, there were many concerns about using a firm AHI threshold level to dictate fitness-to-drive decisions. For example, there were concerns raised about what definition of hypopnea should be used. An individual patient could be above or below the criteria depending on whether arousal- or hypoxemia-based criteria are used. Should the same threshold be used in the context of level 3 ambulatory testing that is performed in many areas in Canada? It was also noted that the relationship between the risk for MVC and the severity of sleep apnea was very weak in the published literature (15).
Certain elements of the sleep history may also help to inform the risks for future MVCs. For example, previous episodes of sleepiness and microsleeps while driving, or near misses and collisions associated with sleepiness are linked to future collision risk and should be elicited in the history (16-18). Self-reported subjective sleepiness, such as the Epworth Sleepiness Scale score (19), should also be taken into account. However, no firm sleepiness threshold could be recommended given the lack of correlation with collisions, and the concern of patients potentially minimizing their symptoms of sleepiness if they believed their ability to drive may be jeopardized.

Measures of objective daytime performance were discussed in terms of their potential usefulness in the assessment of fitness to drive. Some clinicians in the group use these measures of objective daytime sleepiness (eg, multiple sleep latency test or maintenance of wakefulness test [20]) to help ascertain fitness to drive, but this was usually reserved for challenging cases. Again, it was appreciated that there is generally a lack of correlation between measures of daytime sleepiness and MVC risk and, thus, these tests should not be used in isolation. In an individual patient, the risk for collision is influenced by many factors. This includes not only the presence of sleep apnea, but also other factors such as comorbid conditions, medications, sleep/wake schedule, miles driven, road conditions and chronic sleep loss. Assessing fitness to drive in noncommercial drivers must take these factors into account and, thus, is not a simple task. A qualified sleep medicine physician with experience and knowledge assessing risk associated with sleepiness would be the best person to advise driving authorities on issues related to sleep apnea.

It was also believed that the encounter between the patient and the physician would be an excellent opportunity to provide education about the links between sleep disorders and the risk for MVCs, and how this risk may be modified by other factors such as medications, sleep schedules and circadian effects. In addition, this encounter would provide an opportunity to provide counselling about good sleep habits.

\section{Key Message 1:}

Severity of OSA alone is not a reliable predictor of collision risk and should not be used in isolation to assess fitness to drive.

Key Message 2:

The severity of OSA should be considered in the context of other factors (eg, comorbidities, medications, sleep/wake schedule, sleep deprivation, degree of subjective/objective sleepiness, history of collisions) to assess fitness to drive. 


\begin{abstract}
Key Message 3:
A qualified sleep medicine physician with experience and knowledge in assessing risk associated with sleepiness is the best person to advise driving authorities on fitness to drive related to OSA. The decision to restrict driving is ultimately one made by the motor vehicle licencing authority; however, they should take into account the information and recommendations provided by the sleep medicine physician and should follow provincial guidelines.
\end{abstract}

When should patients with OSA who have been restricted from driving be considered fit to drive again? What is the recommended follow-up?

The following should be taken into account when identifying fitness to drive in patients whose OSA has been treated. First, there should be evidence of a clinical response to therapy. Depending on presenting complaints, this could include improvements in subjective sleepiness, fatigue and/or frequency of microsleep. For patients treated with continuous positive airway pressure (CPAP), objective CPAP compliance of at least $4 \mathrm{~h}$ for $>70 \%$ of nights should also be documented (21). Efficacy should also be documented in terms of reversing the physiology of OSA including verification of adequate treatment according to the downloaded CPAP data (eg, AHI ideally $<10$ events/h, but $<20$ events/h acceptable) (11), oximetry, and level 3 sleep study or polysomnography (PSG). The consensus opinion of the CTS-CSS working group was that while treatment is being established, the individual may continue to drive providing that there are no reports of excessive sleepiness during the major wake period while driving, and that the driver has not experienced an MVC associated with falling asleep. In these cases, the demonstration of adequate compliance with CPAP therapy and resolution of daytime sleepiness (if present) would be required to allow driving to resume. CPAP vendors can also play key roles in terms of providing compliance information.

For patients treated with surgery or an oral appliance, adequate sleep apnea treatment (eg, AHI ideally $<10$ events/h, but $<20$ events/h acceptable) should be verified as above. Patient self-reported use of an oral appliance at least $4 \mathrm{~h}$ per night for $>70 \%$ of nights should be documented. Newer technology is becoming increasingly available to assess objective compliance with an oral appliance (22). However, these devices are currently not being used broadly, but they may be useful in the future once more clinical experience with these devices has been accumulated.

Once adequate treatment and clinical response has been established, it is the patient's responsibility to drive safely. Patients should, however, undergo a periodic (eg, at least every five years) review of their OSA treatments, including assessments of symptoms and compliance by their primary care physician or sleep specialist.

\footnotetext{
Key Message 4:

For patients prescribed CPAP, objective CPAP compliance of at least $4 \mathrm{~h}$ for $>70 \%$ of nights should be documented (over at least 30 days). Efficacy should be documented in terms of reversing the symptoms and improvement in sleep apnea monitoring (eg, AHI $\leq 20$ events/h). This could include verification of adequate treatment according to the downloaded CPAP data, oximetry, level 3 sleep study or PSG.

\section{Key Message 5:}

For patients treated with surgery or an oral appliance, verification of adequate sleep apnea treatment should be obtained by PSG or level 3 sleep study (eg, AHI $\leq 20$ events/h). Reported compliance of at least $4 \mathrm{~h}$ per night for $>70 \%$ of nights should be documented (oral appliance). We recognize the limitations of subjective reporting for oral appliances, and suggest using devices with objective compliance monitoring once available.
}

\section{Key Message 6:}

A driver diagnosed with OSA may be recertified as fit to drive based on assessment of symptoms and demonstrating compliance with treatment. (Frequency of assessment should be closely aligned with the provincial driver's license renewal period) Minimally acceptable compliance with positive airway pressure treatment consists of at least $4 \mathrm{~h}$ per day of use on $70 \%$ of days (over at least 30 days, and within the previous 90 days). With oral appliances, reported use should be at least $70 \%$ of nights. For noncommercial drivers, recertification of fitness to drive can be performed by either a sleep physician or the patient's family physician.

Should recommendations be different for commercial drivers? If so, how? Should all professional/commercial drivers be screened for OSA? If so, how?

For drivers of commercial vehicles, recommendations for fitness to drive should be more stringent than noncommercial drivers for many reasons (23). First, commercial drivers spend more time on the road, thus increasing their overall collision risk (24). Second, because commercial vehicles are generally larger than noncommercial vehicles, the collisions may result in greater property damage and human morbidity/ mortality (25). Third, drivers (especially long-haul truck drivers) may be subjected to abnormal sleep/wake schedules resulting in circadian misalignment and sleep deprivation. Fourth, commercial drivers and other professions that affect public safety are usually held to a higher medical standard than those that do not. For example, fitness-to-drive criteria based on hearing and vision impairment is more stringent for commercial than noncommercial drivers. Of note, commercial drivers would be considered as members of a safety-critical occupation and should ideally be seen within four weeks of referral to a sleep centre as per the 2011 CTS sleep apnea guidelines.

Much of the discussion at the workshop meeting and subsequent telephone conferences focused on the proposed FMCSA recommendations from the MEP and whether these would be reasonable to adopt in Canada. Each recommendation was extensively reviewed and potentially modified based on the suggestions of the working group until consensus was achieved. The MEP recommendations and adapted recommendations for Canadian practitioners are outlined in Table 2.

It was agreed that screening for OSA should be undertaken in commercial drivers given the relatively high prevalence of OSA demonstrated in this group (24). A two-stage process was suggested to be the most feasible option. A screening evaluation based on symptoms, questionnaires and anthropomorphic measures (eg, body mass index [BMI] and neck circumference) could be used to identify drivers at high risk for sleep apnea who require further testing. An alternative would be to screen all drivers using PSG or level 3 testing; however, this option was not believed to be feasible. The working group believed that the screening process should be overseen by a physician with appropriate sleep medicine training.

The Berlin questionnaire has been used in more general populations (26) and could be considered as a screening tool in this context. Although it has not been validated in a general population, use of the sleep apnea clinical score (that relies on neck circumference and hypertension in addition to symptoms) may be more appropriate to identify drivers who are at increased risk (27). Finally, similar to the FMCSA guidelines, drivers with a high BMI $\left(>35 \mathrm{~kg} / \mathrm{m}^{2}\right)$, regardless of symptoms, should also be considered high risk.

Concerns were raised that drivers may minimize their symptoms if their driving fitness was considered to be at risk. Recent studies have suggested that this may be an issue, and that relying on purely subjective reports of symptoms may be suboptimal for screening (15). As such, screening should likely also include one or more objective measures (eg, neck circumference, BMI, blood pressure).

In terms of confirmatory testing, PSG was considered to be the best test. However, because of potential lack of availability of PSG testing in some areas of Canada (29), a level 3 study is a reasonable alternative. 
Ideally, before initiating any therapy, the individual should be seen by a qualified sleep medicine physician. However, the working group was cognizant of the resource implications of this given the lack of access to sleep medicine physicians, especially in more rural areas. Therefore, a physician who has experience with the management and monitoring of patients with OSA would be a reasonable alternative. There is a need to develop training programs for primary care physicians to assess fitness to drive in patients with OSA.

Key Message 7:
Assessment of fitness to drive should be more stringent for patients
driving commercial vehicles.
Key Message 8:
The MEP recommendations to the FMCSA were adapted for
Canadian practitioners and are detailed in Table 2 .

\section{DISCUSSION}

The present document is the first Canadian position statement addressing the issue of OSA and driving at a national level. The diagnosis and management of this condition in both commercial and noncommercial drivers varies significantly across Canada, highlighting the need for standardization in this area. The CTS-CSS working group embarked on a process to provide Canadian practitioners with an overview of the current provincial regulations and FMCSA guidelines, thereby providing a strong basis for adaptation to Canadian practice.

There were many challenges encountered during the development of the present position paper. For example, the CTS-CSS working group experienced difficulty in accessing some provincial regulations on driving in patients with OSA. A significant percentage of the regulations were obtained by personal communication. For these to have a meaningful benefit, the provincial regulations need to be more accessible to sleep medicine practitioners, which calls for greater collaboration between regulatory bodies and sleep medicine experts.

Although there are compelling data documenting increased rates of MVCs in patients with OSA, many issues require clarification from more definitive studies. For example, the optimal frequency of followup has not received sufficient scientific scrutiny. As such, we had to rely on consensus for many of our key messages. The CTS-CSS working group hopes that the present document will stimulate discussion on this important topic in Canada and will form the basis for additional research studies.

Another major focus of discussion was the definition of what constitutes sleep-related expertise. There is currently no certification for sleep medicine by the Royal College of Physicians and Surgeons of Canada (RCPSC), making it difficult to provide recommendations in this regard. In addition, by necessity in many areas, OSA patients are managed predominately by their primary care physician. Developing a RCPSC-approved training program in sleep medicine would help to address this shortfall in medical expertise.

Given that sleep apnea is a very common condition, we acknowledge that implementation and adherence to the standards outlined in the present statement may present challenges in some provinces. In particular, access to sleep diagnostic services and practitioners with expertise in the evaluation and management of patients with sleep disorders may be significant barriers in some parts of the country. Nevertheless, we believe that it was important to present what we considered to be reasonable practice standards. We hope that the current document will foster more discussion and research in this area.

EDITORIAL INDEPENDENCE: The Sleep Disordered Breathing Clinical Assembly is accountable to the CTS Respiratory Guidelines Committee and the CTS Board of Directors. The Sleep Disordered Breathing Clinical Assembly is functionally and editorially independent from any funding sources of the CTS. The CTS receives unrestricted grants that are combined into a central operating account to facilitate the knowledge translation activities of CTS Clinical Assemblies. No funders played a role in the collection, review analysis or interpretation of the literature or in any decisions regarding the key messages presented in this document.

DISCLOSURES: Members of the Sleep Disordered Breathing Clinical Assembly declared potential conflicts of interest at the time of appointment and these were updated throughout the development process in accordance with CTS Conflict of Interest Disclosure Policy. Individual member conflict of interest statements are posted at www.respiratoryguidelines.ca/guideline/sleep-apnea.

ACKNOWLEDGEMENTS: The authors thank the expert peer reviewers: Dr Kris Fraser (Calgary, Alberta), Tom Kenny (RTL-Westcan Group of Companies, Edmonton, Alberta), Dr Judith Leech (Ottawa, Ontario). The authors also thank Tom Hakemi for his legal expertise. The authors acknowledge the contributions of the CIHR Sleep Team Grant to the OSA and Driving workshop that was held in Vancouver, British Columbia.

\section{REFERENCES}

1. Barger LK, Cade BE, Ayas NT, et al. Impact of extended duration work shifts ( $>24$ hours) on intern sleep and risk of motor vehicle crashes. N Engl J Med 2005;352:125-34.

2. George CF. Sleep 5: Driving and automobile crashes in patients with obstructive sleep apnoea/hypopnoea syndrome. Thorax 2004;8:61-72.

3. Public Health Association of Canada. The Canadian Community Health Survey: Rapid Response on sleep apnea. <www.statcan.gc. ca/daily-quotidien/091208/dq091208d-eng.htm>

(Accessed October 12, 2013).

4. Young T, Palta M, Dempsey J, Skatrud J, Weber S, Badr S. The occurrence of sleep-disordered breathing among middle-aged adults. N Engl J Med 1993;32:1230-5.

5. Ayas NT, FitzGerald JM, Fleetham J, et al. Cost-effectiveness of continuous positive airway pressure (CPAP) for moderate to severe obstructive sleep apnea hypopnea. Arch Intern Med 2006;166:977-84.

6. Ellen RL, Marshall SC, Palayew M, et al. Systematic review of motor vehicle crash risk in persons with sleep apnea. J Clin Sleep Med 2009;5:573-81.

7. Sassani A, Findley LJ, Kryger M, Goldlust E, George C, Davidson TM. Reducing motor-vehicle collisions, costs, and fatalities by treating obstructive sleep apnea syndrome. Sleep 2004;27:453-8.

8. George CF. Reduction in motor vehicle collisions following treatment of sleep apnoea with nasal CPAP. Thorax 2001;56:508-12.

9. Strohl KP, Brown BD, Collop N, et al. An Official American Thoracic Society clinical practice guideline: Sleep apnea, sleepiness, and driving risk in noncommercial drivers: An update of a 1994 statement. Am J Respir Crit Care Med 2013;187:1259-66.

10. Motor Carrier Safety Advisory Committee. Federal Motor Carrier Safety Administration. Final Report: OSA (MCSAC/MRB February 2012 Meeting) (Task 11-05). <http://mcsac.fmcsa.dot.gov/ Reports.htm> (Accessed December 3, 2012).

11. J Fleetham, N Ayas, D Bradley, et al; The Canadian Thoracic Society Sleep Disordered Breathing Committee. Canadian Thoracic Society 2011 guideline update: Diagnosis and treatment of sleep disordered breathing. Can Respir J 2011;18:25-47.

12. CMA Driver's Guide: Determining Medical Fitness to Operate Motor Vehicles, 8th edn. <www.cma.ca/driversguide> (Accessed September 21, 2013).

13. Anacoli-Israel S, Czeisler CA, George CP, et al. Expert Panel Recommendations: Obstructive Sleep Apnea and Commercial Motor Vehicle Driver Safety, January 2008.<www.fmcsa.dot.gov/ rules-regulations/TOPICS/mep/report/Sleep-MEP-PanelRecommendations-508.pdf> (Accessed December 6, 2012).

14. Canadian Thoracic Society: Canadian Respiratory Guidelines. Clinical Practice Guidelines Production Manual. <www. respiratoryguidelines.ca/sites/all/files/production_manual.pdf $>$ (Accessed November 29, 2013).

15. Mulgrew AT, Nasvadi G, Butt A, et al. Risk and severity of motor vehicle crashes in patients with obstructive sleep apnoea/ hypopnoea. Thorax 2008;63:536-41.

16. Blazejewski S, Girodet PO, Orriols L, et al. Factors associated with serious traffic crashes: A prospective study in southwest France; CESIR Group. Arch Intern Med 2012;172:1039-41. 
17. Sagaspe P, Taillard J, Bayon V, et al. Sleepiness, near-misses and driving accidents among a representative population of French drivers. J Sleep Res 2010;19:578-84.

18. Philip P, Sagaspe P. Sleep and accidents. Bull Acad Natl Med 2011;195:1635-43 (In French).

19. Johns MW. A new method for measuring daytime sleepiness: The Epworth Sleepiness Scale. Sleep 1991;14:540-5.

20. Philip P. Can the MSLT be a useful tool to assess motor vehicle crash risk in sleepy drivers? Sleep 2010;33:729-30.

21. Schwab RJ, Badr SM, Lawrence E, et al. An Official American Thoracic Society Statement: Continuous positive airway pressure adherence tracking systems: The optimal monitorings strategies and outcome measures in adults. Am J Respir Crit Care Med 2013;188:613-20.

22. Vanderveken OM, Dieltjens M, Wouters K, et al. Objective measurement of compliance during oral appliance therapy for sleep-disordered breathing. Thorax 2013;68:91-6.

23. Teng AY, Won C. Implications of OSA on work and work disability including drivers. Clin Chest Med 2012;33:731-44.

24. Gurubhagavatula I, Maislin G, Nkwuo J, Pack AI. Occupational screening for obstructive sleep apnea in commercial drivers. Am J Respir Crit Care Med 2004;170:371-6.

25. Talmage JB, Hudson TB, Hegmann KT, Thiese MS. Consensus criteria for screening commercial drivers for obstructive sleep apnea: Evidence of efficacy. J Occup Environ Med 2008;50:324-9.

26. Moreno CR, Carvalho FA, Lorenzi C, et al. High risk of obstructive sleep apnea estimated by the Berlin questionnaire: Prevalence and associated factors. Chronbiol Int 2014;21:871-9.

27. Flemons WW, Whitelaw WA, Brant R, Remmers JE. Likelihood ratios for a sleep apnea clinical prediction rule. Am J Respir Crit Care Med 1994;150:1279-85.

28. Xie W, Chakrabarty S, Levine R, et al. Factors associated with obstructive sleep apnea among commercial drivers. J Occup Environ Med 2011;53:169-73.

29. Evans J, Skomro R, Driver H, et al. Sleep laboratory test referrals in Canada: Sleep Apnea Rapid Response survey. Can Respir J 2014;21:e4-e10.
30. Ministry of Public Safety and Solicitor General Office of the Superintendent of Motor Vehicles 2010 BC Guide in Determining Fitness to Drive. <www.pssg.gov.bc.ca/osmv/shareddocs/2010-guidein-determining-fitness-to-drive.pdf> (Accessed January 10, 2012).

31. Government of Alberta Transportation: Driver Fitness and Monitoring. <www.transportation.alberta.ca/542.htm> (Accessed January 10, 2012).

32. Ontario Highway Traffic Act. Section 203. <www.e-laws.gov.on.ca/ html/statutes/english/elaws_statutes_90h08_e.htm\#BK301> (Accessed January 10, 2012).

33. Canadian Council of Motor Transport Administrators. Determining Driver Fitness in Canada, 13th edn <http://ccmta.ca/images/ publications/pdf//Determining-Driver-Fitness-In-Canada-Final.pdf> (Accessed on November 21, 2013)

34. College of Physicians and Surgeons of Nova Scotia: Guidelines Regarding Reporting Requirements for Nova Scotia Physicians. <www.cpsns.ns.ca/DesktopModules/Bring2mind/DMX/Download. asp $\mathbf{2}$ Command $=$ Core_Download\&EntryId $=55 \&$ Portalld $=0 \&$ Tab Id=180> (Accessed January 10, 2012).

35. Canadian Council of Motor Transport Administrators. National Safety Code. <http://ccmta.ca/en/publications/national-safety-code/ item/national-safety-code> (Accessed November 21, 2013).

36. Berry RB, Budhiraja R, Gottlieb DJ, et al. Rules for scoring respiratory events in sleep: Update of the 2007 AASM Manual for the Scoring of Sleep and Associated Events. Deliberations of the Sleep Apnea Definitions Task Force of the American Academy of Sleep Medicine. J Clin Sleep Med 2012;8:597-619.

37. Blackman A, McGregor C, Dales R, et al. Canadian Sleep Society/ Canadian Thoracic Society position paper on the use of portable monitoring for the diagnosis of obstructive sleep apnea/hypopnea in adults. Can Respir J 2010;17:229-32. 


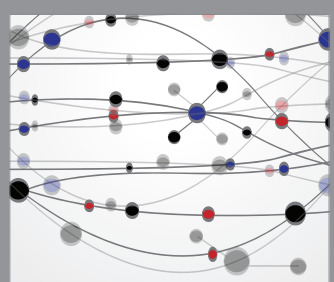

The Scientific World Journal
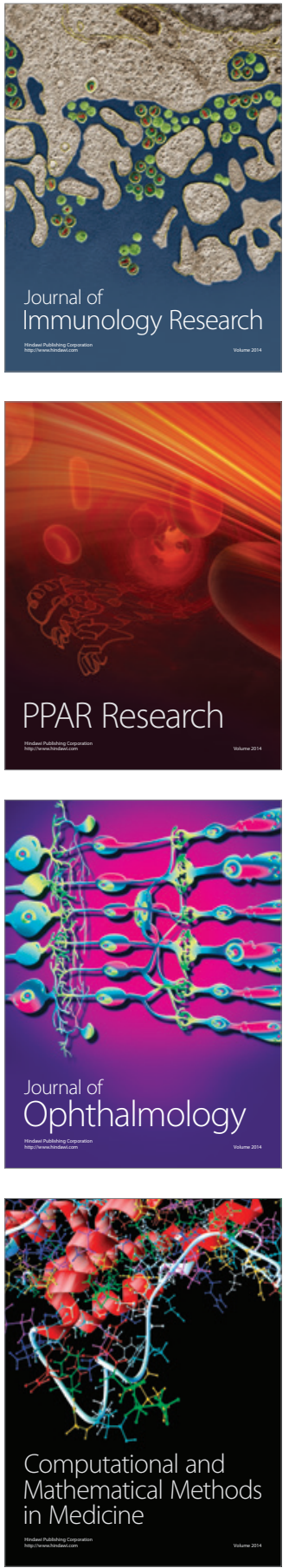

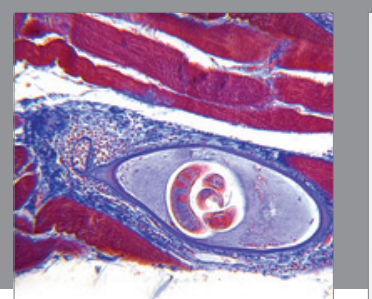

Gastroenterology Research and Practice

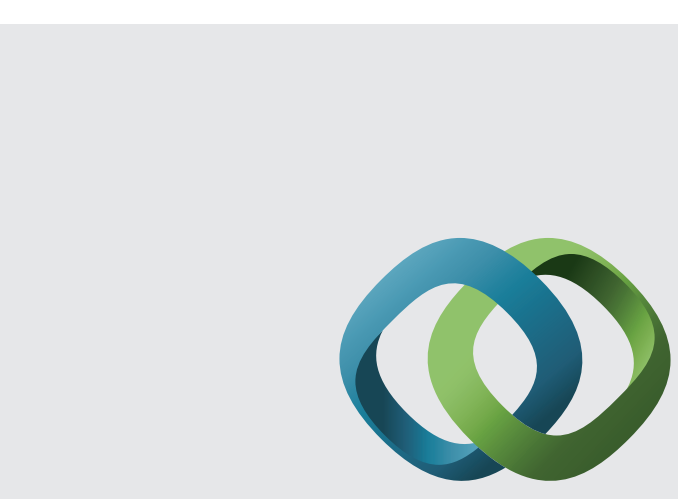

\section{Hindawi}

Submit your manuscripts at

http://www.hindawi.com
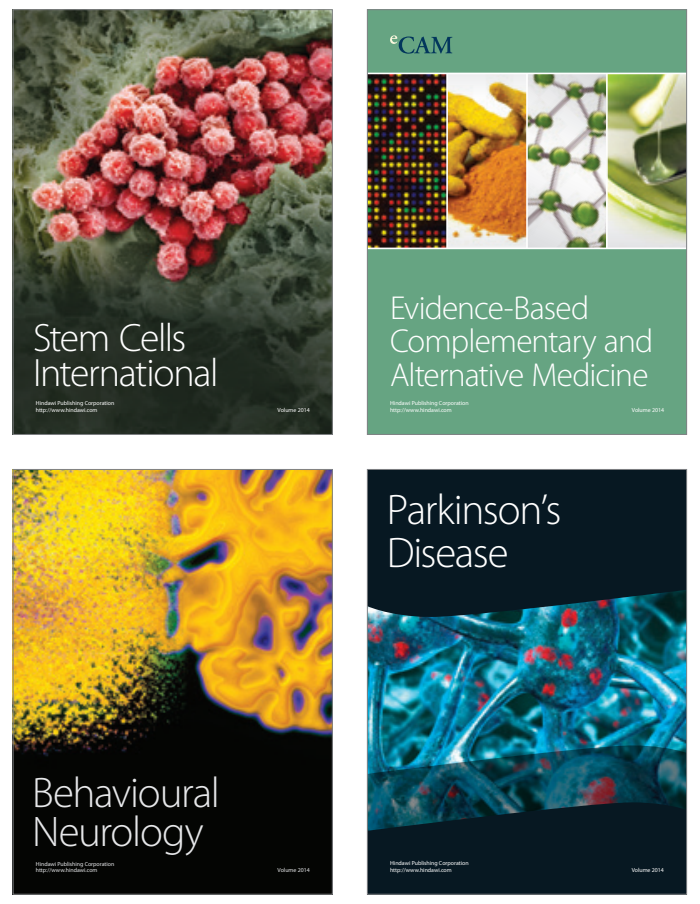
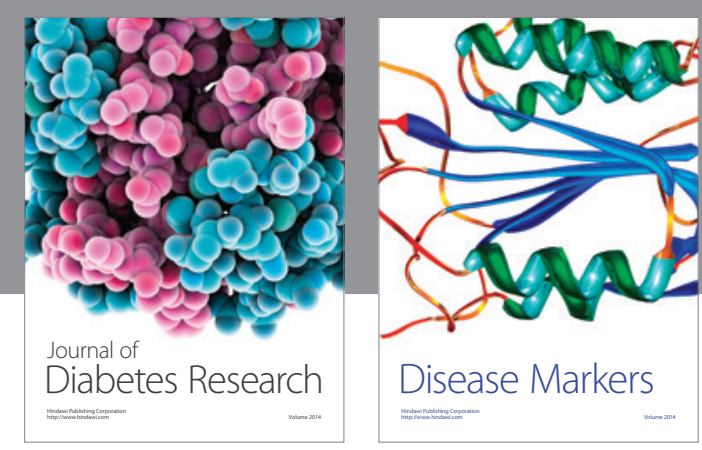

Disease Markers
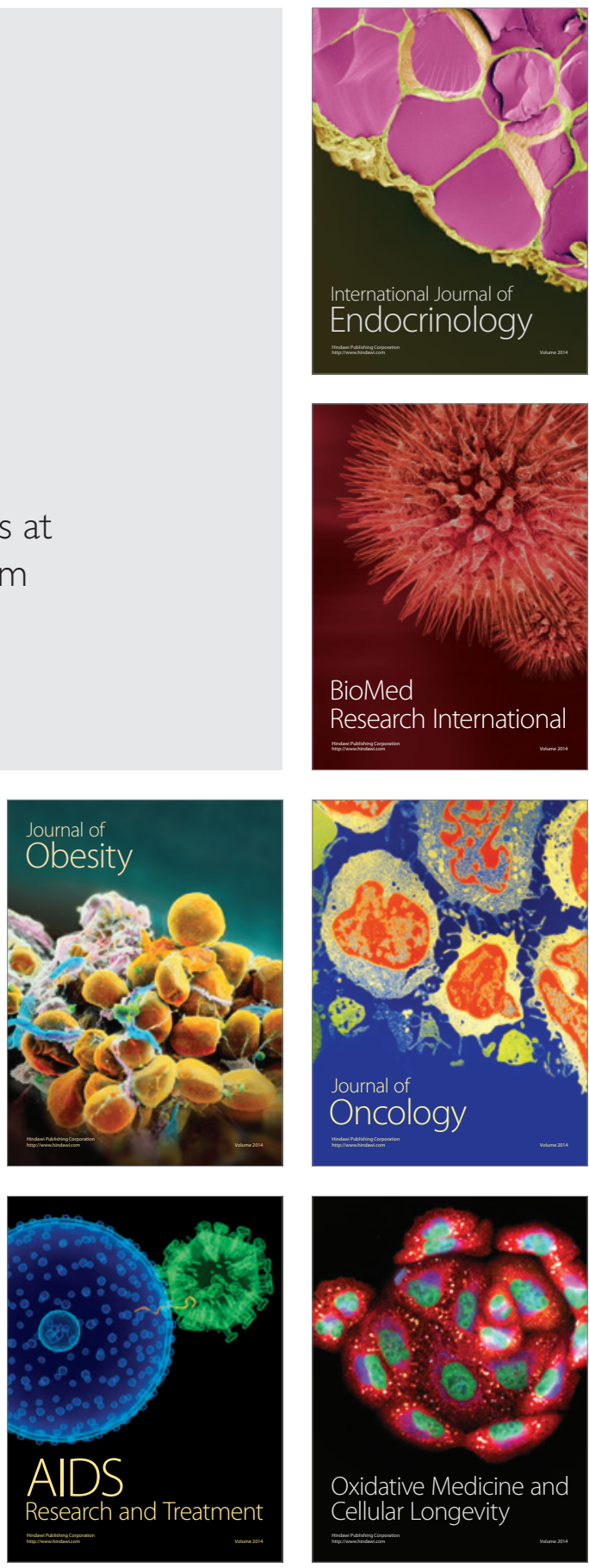